\title{
Kualitas Pelayanan Dan Pengaruhnya Terhadap Loyalitas Pelanggan Yang Di Mediasi Oleh Kepuasan Di Bank Muamalat Jombang
}

\author{
Chusnul Rofiah ${ }^{1}$, Dwi Wahyuni ${ }^{2}$ \\ STIE PGRI Dewantara Jombang ${ }^{1}$, STKIP PGRI Jombang ${ }^{2}$ \\ chusnulrofiah@yahoo.com ${ }^{1}$,dwiwahyuni.stkipjb@gmail.com ${ }^{2}$
}

Diserahkan: 5 Nopember 2016, Diterima: 24 April 2017

\begin{abstract}
Customer satisfaction is important to the company, because satisfied customers will ultimately become loyal customers and can promote what customers feel to other prospects. If the company can create maximum satisfaction to customers, then the company will be able to create loyal customers. The type of research conducted is explanatory research (explanatory research). The population in this study are the customers of Bank Muamalat using a sample of 90 customers. Accidental sampling. . Variables in the study amounted to three variables namely service quality variables $(x)$, customer satisfaction (y1) and loayalitas customer (y2). The research instruments used were questionnaires and interviews. Hypothesis testing of research conducted by using path analysis model (path analysis) and data processing using SPSS program. Based on the results of the research shows that: 1) Customer satisfaction can be built from good service Quality, 2) Customer satisfaction can build a customer loyalty, 3) To build customer loyalty, can be through customer satisfaction as well as from the quality of service Both from Bank Muamalat Jombang.

Keywords: Service Quality, Loyalty, Satisfaction
\end{abstract}

\begin{abstract}
Abstrak
Kepuasan pelanggan merupakan hal penting bagi perusahaan, karena pelanggan yang puas pada akhirnya akan menjadi pelanggan yang loyal dan dapat mempromosikan apa yang pelanggan rasakan kepada calon pelanggan lain. Apabila perusahaan dapat menciptakan kepuasan yang maksimal kepada pelanggan, maka perusahaan akan dapat menciptakan pelanggan yang loyal. Jenis penelitian yang dilakukan adalah penelitian eksplanasif (explanatory research). Populasi dalam penelitian ini adalah para nasabah Bank Muamalat dengan menggunakan sampel sebanyak 90 nasabah. Pengambilan sampel secara aksidental. . Variabel dalam penelitian berjumlah tiga variabel yaitu variabel kualitas pelayanan (x), kepuasan pelanggan (y1) dan loayalitas pelanggan (y2). Instrumen penelitian yang digunakan adalah kuesioner dan wawancara. Pengujian hipotesis penelitian dilakukan dengan menggunakan model analisis jalur (path analysis) dan pengolahan data menggunakan program SPSS. Berdasarkan hasil penelitian menunjukkan bahwa: 1) Kepuasan pelanggan dapat dibangun dari Kualitas pelayanan yang baik, 2) Kepuasan yang dirasakan pelanggan dapat membangun sebuah loyalitas pelanggan, 3) Untuk membangun loyalitas pelanggan, dapat melalui kepuasan yang dirasakan oleh pelanggan dan juga dari kualitas pelayanan yang baik dari Bank Muamalat Jombang.
\end{abstract}

Kata kunci : Kualitas Pelayanan, Loyalitas, Kepuasan

\section{A. PENDAHULUAN}

Perkembangan dan peningkatan jasa pada perusahaan dari tahun ke tahun semakin menjadi perhatian masyarakat. Hal ini dapat dilihat dari adanya persaingan yang ketat dalam hal kualitas pelayanan. Dalam kondisi persaingan yang semakin ketat tersebut, hal utama yang diprioritaskan oleh perusahaan yang bergerak dalam bidang pelayanan adalah kepuasan pelanggan agar dapat bertahan yang mengakibatkan peningkatan loyalitas untuk menguasai pasar.Perusahaan dituntut berusaha membuat pelanggan merasa puas dengan memberikan penawaran dan pelayanan yang lebih baik, mengingat perusahaan harus mampu untuk dapat mempertahankan posisi pasarnya 
ditengah persaingan yang semakin ketat. Salah satunya dengan mengembangkan strategi untuk mempertahankan konsumen melalui kualitas jasa. Strategi yang ditempatkan untuk dapat mempertahankan loyalitas pelanggan adalah dengan meyediakan jasa layanan yang berkualitas, sehingga disini pihak manajemen perusahaan harus memperhatikan kualitas yang sesuai dengan yang diharapkan konsumen.

Salah satu industri jasa yang saat ini mengalami persaingan yang cukup ketat adalah industri perbankan. Bisnis perbankan merupakan bisnis jasa yang berdasarkan pada azas kepercayaan, sehingga masalah kualitas layanan menjadi salah satu faktor yang menentukan keberhasilan dalam sebuah usaha. Pelayanan dalam dunia perbankan saat ini begitu pesat baik inovasi tekhnologi, produk dan pelayanan termasuk pada Bank Muamalat.

Upaya peningkatan kualitas pelayanan oleh Bank Muamalat Jombang bersifat inovatif dan berorientasi pada kepuasan dan loyalitas pelanggan. Namun masih muncul pertanyaan, apakah hal tersebut telah benar-benar dapat memberikan kepuasan yang menumbuhkan sebuah loyalitas bagi pelanggan Bank Muamalat Jombang bila dilihat dari lima dimensi pelayanan yaitu tangibles (bukti langsung), reliability (kehandalan), responsiveness (daya tanggap), assurance (jaminan) dan empathy (empati).

Menurut Tjiptono, Chandra dan Adriana (2007), Secara sederhana, kualitas dapat diartikan sebagai produk yang bebas cacat, dengan kata lain produk sesuai dengan standar (target sasaran atau persyaratan yang bisa didefinisikan, diobservasi dan diukur). Menurut Kotler dan Keller (2007), Kepuasan adalah perasaan senang atau kecewa seseorang yang muncul setelah membandingkan kinerja (hasil) produk yang dipikirkan terhadap kinerja (atau hasil) yang diharapkan. Jika kinerja berada dibawah harapan, pelanggan tidak puas. Jika kinerja memenuhi harapan, pelanggan puas, jika kinerja melebihi harapan, pelanggan amat puas atau senang.

Menurut Kotler dan Keller (2009), Jika konsumen puas, konsumen mungkin ingin membeli produk itu kembali. Pelanggan yang puas juga cenderung mengatakan hal-hal baik tentang merek. Di pihak lain, konsumen yang kecewa mungkin mengabaikan atau mengembalikan produk. Konsumen mungkin mencari informasi yang memastikan nilai produk yang tinggi. Konsumen mungkin mengajukan tuntutan umum dengan melayangkan keluhan kepada perusahaan, menggunakan pengacara, atau melayangkan keluhan ke kelompok lain (seperti badan bisnis, swasta atau pemerintah)

Dalam upaya untuk mempertahankan pelanggan, faktor terpenting yang harus diprioritaskan yaitu kepuasan. Akan tetapi agar lebih maksimal kalau perusahaan dapat mengukur kepuasan pelanggan secara teratrur. Karena dengan mengukur kepuasan pelanggan perusahaan dapat mengetahui seberapa besar kepuasan yang dirasakan oleh pelanggan.

Menurut Kotler (2007), sebuah perusahaan dikatakan bijaksana kalau mengukur kepuasan pelanggannya secara teratur, karena kunci untuk mempertahankan pelannggan adalah kepuasan. Pelanggan yang sangat puas umumnya lebih lama setia, membeli lebih banyak ketika perusahaan memperkenalkan produk baru dan meningkatkan produksi yang ada, membicarakan hal-hal yang menyenagkan tentang perusahaan dan produkproduknya, tidak banyak memberi perhatian pada merek pesaing dan tidak terlalu peka terhadap harga, menawarkan ide produk atau layanan kepada perusahaan, dan lebih sedikit biaya untuk melayani pelanggan ini daripada pelanggan baru karena transaksinya bersifat rutin.

Menurut Griffin (2002), Loyalitas konsumen lebih banyak dikaitkan dengan perilaku (behavior) dari pada dengan sikap. Jika seseorang merupakan konsumen loyal, 
konsumen akan menunjukkan perilaku pembelian yang didefinisikan sebagai pembelian non-random yang diungkapakan dari waktu ke waktu oleh beberapa unit pengambilan keputusan.

Penelitian ini menguji variabel kualitas kualitas pelayanan terhadap kepuasan dan loyalitas nasabah. Secara spesifik permasalahan penelitian ini adalah: 1) Apakah kualitas layanan berpengaruh terhadap loyalitas pelanggan? 2) Apakah kualitas layanan berpengaruh terhadap loyalitas pelanggan yang di mediasi oleh kepuasan?

Hasil dari penelitian ini diharapkan memberikan manfaat kepada pihak-pihak yang terkait, terutama bagi Bank Muamalat yaitu dapat menjadi masukan bagi pihak bank untuk dapat mengetahui persepsi nasabah tentang kualitas pelayanan yang ada pada Bank Muamalat di Kota Jombang.

\section{B. Landasan Teori}

\section{Kualitas Layanan}

Menurut Tjiptono, Chandra dan Adriana (2007), Secara sederhana, kualitas dapat diartikan sebagai produk yang bebas cacat, dengan kata lain produk sesuai dengan standar (target sasaran atau persyaratan yang bisa didefinisikan, diobservasi dan diukur). Dalam kasus pemasaran jasa, dimensi kualitas yang paling sering dijadikan acuan adalah :

1. Reliabilitas, yakni kemampuan memeberikan layanan yang dijanjikan dengan segera, akurat dan memuaskan.

2. Responsivitas, yaitu keinginan dan kesediaan para karyawan utuk membantu para pelanggan dan memberikan layanan dengan tanggap.

3. Jaminan (assurance), mencakup pengetahuan, kompetensi, kesopanan dan sifat dapat dipercaya yang dimiliki para karyawan; bebas dari bahaya fisik, resiko atau keragu-raguan.

4. Empati, meliputi kemudahan dalam menjalin hubungan, komunikasi yang efektif, perhatian personal, dan pemahaman atas kebutuhan individual para pelanggan.

5. Bukti fisik (tangibles), meliputi fasilitas fisik, perlengkapan karyawan, dan sarana komunikasi.

Menurut Kotler (2007) definisi pelayanan adalah setiap tindakan atau kegiatan yang dapat ditawarkan oleh suatu pihak kepada pihak lain, yang pada dasarnya tidak berwujud dan tidak mengakibatkan kepemilikan apapun. Produksinya dapat dikaitkan atau tidak dikaitkan pada satu produk fisik.Pelayanan merupakan perilaku produsen dalam rangka memenuhi kebutuhan dan keinginan konsumen demi tercapainya kepuasan pada konsumen itu sendiri.Kotler juga mengatakan bahwa perilaku tersebut dapat terjadi pada saat, sebelum dan sesudah terjadinya transaksi.

\section{Kepuasan Pelanggan}

Menurut Kotler dan Keller (2007), Kepuasan adalah perasaan senang atau kecewa seseorang yang muncul setelah membandingkan kinerja (hasil) produk yang dipikirkan terhadap kinerja (atau hasil) yang diharapkan. Menurut Mowen dan Minor (2007) Kepuasan konsumen (Consumer Satisfaction) didefinisikan sebagai keseluruhan sikap yang ditunjukkan konsumen atas barang atau jasa setelah mereka memperoleh dan menggunakannya. Menurut Kotler (1997), Kepuasan merupakan tingkat perasaan dimana seseorang menyatakan hasil perbandingan atas kinerja produk jasa yang diterima dengan yang diharapkan.

Apabila ditinjau lebih lanjut, pencapaian kepuasan pelanggan melalui kualitas pelayanan dapat ditingkatkan dengan beberapa pendekatan berikut ini : 
1. Memperkecil kesenjangan-kesenjangan yang terjadi antara pihak manajemen dan pelanggan.

2. Perusahaan harus mampu membangun komitmen bersama untuk menciptakan visi dalam perbaikan proses pelayanan, yang termasuk didalamnya adalah memperbaiki cara berfikir, perilaku, dan pengetahuan dari semua sumber daya manusia yang ada.

3. Memberikan kesempatan kepada pelanggan untuk menyampaikan keluhan.

4. Mengembangkan dan menerapkan partnership accountable, proaktif dan partnership marketing sesuai dengan situasi pemasaran. Perusahaan menghubungi pelanggan setelah proses pelayanan terjadi untuk mengetahui kepuasan dan harapan pelanggan (akuntabel). Perusahaan menghubungi pelanggan dari waktu ke waktu untuk mengetahui perkembangan pelayanan (proaktif). Sementara itu partnership marketing adalah pendekatan dimana perusahaan membangun kedekatan dengan pelanggan yang bermanfaat untuk meningkatkan citra dan posisi perusahaan di pasar.

\section{Loyalitas Pelanggan}

Loyalitas secara harfiah diartikan sebagai kesetiaan, yaitu kesetiaan seseorang terhadap suatu objek. Loyalitas sebagai kondisi dimana pelanggan mempunyai sikap positif terhadap suatu merek, mempunyai komitmen terhadap merek tersebut, dan bermaksud meneruskan pembeliannya dimasa mendatang. Ini berarti loyalitas selalu berkaitan dengan preferensi pelanggan dan pembelian actual. Lupiyoadi (2009).

Menurut Griffin (2003), Loyalitas konsumen lebih banyak dikaitkan dengan perilaku (behavior) dari pada dengan sikap. Jika seseorang merupakan konsumen loyal, konsumen akan menunjukkan perilaku pembelian yang didefinisikan sebagai pembelian non-random yang diungkapakan dari waktu ke waktu oleh beberapa unit pengambilan keputusan. Dua kondisi penting yang berhubungan dengan loyalitas adalah:

1. Retensi pelanggan (costumer retantion) menjelaskan lamanya hubungan dengan pelanggan. Tingkat retensi pelanggan adalah presentase pelanggan yang telah memenuhi sejumlah pembelian ulang selama periode waktu yang terbatas.

2. Total pangsa pelanggan (total share of costumer) suatu perusahaan menunjukkan presentase dari anggaran pelanggan yang dibelanjakan keperusahaan.

Menurut Tjiptono (2002) mengemukakan enam indikator yang bisa digunakan untuk mengukur loyalitas konsumen yaitu: 1) Pembelian ulang, 2) Kebiasaan mengkonsumsi merek tersebut, 3) Selalu menyukai merek tersebut, 4) Tetap memilih merek tersebut, 5) Yakin bahwa merek tersebut yang terbaik, 6) Merekomendasikan merek tersebut pada orang lain.

\section{Hubungan Variabel Kualitas pelayanan Terhadap Kepuasan Pelanggan}

Kotler dan Keller (2007) Menyatakan bahwa kualitas pelayanan berpengaruh dan kepuasan konsumen akan membentuk minat membeli atau menggunakan kembali suatu produk. Artinya semakin baik bentuk pelayanan yang diberikan dan didukung oleh tingkat kepuasan yang tinggi tentunya akan membentuk loyalitas pada konsumen. Penelitian sebelumnya mengenai kualitas pelayanan terhadap kepuasan pelanggan yang telah dilakukan oleh Desrika (2013) menyatakan bahwa, Kualitas pelayanan berpengaruh positif terhadap kepuasan pelanggan. Berdasarkan uraian tersebut maka terdapat keterkaitan antara kualitas pelayanan terhadap kepuasan pelanggan, artinya semakin baik pelayanan yang diberikan maka secara langsung pelanggan merasa puas dengan apa yang telah diterima. Pelanggan yang merasa puas dengan kualitas pelayanan yang diberikan maka akan memiliki sikap yang positif, sehingga pelanggan akan puas. 
Dan apabila kualitas pelayanan yang diberikan sangat buruk maka pelanggan cenderung untuk tidak kembali.

\section{Hubungan Variabel Kepuasan Terhadap Loyalitas}

Kepuasan pelanggan adalah Perasaan senang atau kecewa seseorang yang muncul setelah membandingkan antara persepsi atau kesan pelanggan terhadap hasil suatu produk dan harapan-harapan pelanggan. Keberhasilan perusahaan apabila karyawan mampu memberikan pelayanan yang baik, sehingga pelanggan merasa puas dan di mata pelanggan citra perusahaan menjadi baik dan bersifat positif. Hal tersebut dapat menumbuhkan loyalitas pelanggan Kotler (2007). karakteristik pelanggan yang loyal menurut Griffin (2003) adalah sebagai berikut: 1) Melakukan pembelian berulang secara teratur, 2) Membeli antarlini produk dan jasa, 3) Mereferensikan keada orang lain, 4) Menunjukan kekebalan terhadap tarikan dari pesaing. Penelitian sebelumnya tentang loyalitas pelanggan yang dilakukan oleh Ishak dan Luthfi (2011) membuktikan bahwa kepuasan berpengaruh terhadap loyalitas, hasil tersebut didukung oleh penelitian yang telah dilakukan oleh Alfian (2010) membuktikan bahwa kepuasan berpengaruh positif terhadap loyalitas pelanggan.

\section{Hubungan Variabel Kualitas Pelayanan Terhadap Loyalitas Pelanggan}

Apabila kualitas pelayanan yang diberikan perusahaan sesuai dengan harapan dan kinerja maka konsumen akan senang karena harapan dan kinerja dari pelayanan tersebut sudah baik dan loyalitas konsumen secara langsung akan timbul pada perusahaan tersebut. Menurut hasil penelitian yang dilakukan oleh Prasetyo (2007) menyatakan bahwa hipotesis yang menyatakan bahwa "kualitas layanan berpengaruh secara langsung terhadap loyalitas" diterima kebenarannya.

\section{Hubungan Kualitas pelayanan Terhadap Loyalitas Pelanggan Yang Dimediasi Melalui Kepuasan}

Kualitas memiliki hubungan yang erat dengan kepuasan pelanggan dalam menentukan loyalitas konsumen. Kualitas memberikan suatu dorongan kepada pelanggan untuk menjalin ikatan hubungan yang kuat dengan perusahaan. Dalam jangka panjang ikatan seperti ini memungkinkan perusahaan untuk memahami dengan seksama harapan pelanggan serta kebutuhan mereka. Dengan demikian, perusahaan dapat meningkatkan kepuasan pelanggan melalui pemberian pelayanan yang menyenangkan tentu akan tercipta loyalitas yang tinggi pada konsumen terhadap perusahaan, (Tjiptono, 2006). Penelitian sebelumya tentang pengaruh kualitas pelayanan terhadap loyalitas yang dimediasi oleh kepuasan pelanggan yang dilakukan oleh Puspitsari dan Edris (2011), menunjukkan bahwa kualitas pelayanan berpengaruh terhadap loyalitas yang di mediasi oleh kepuasan pasien.

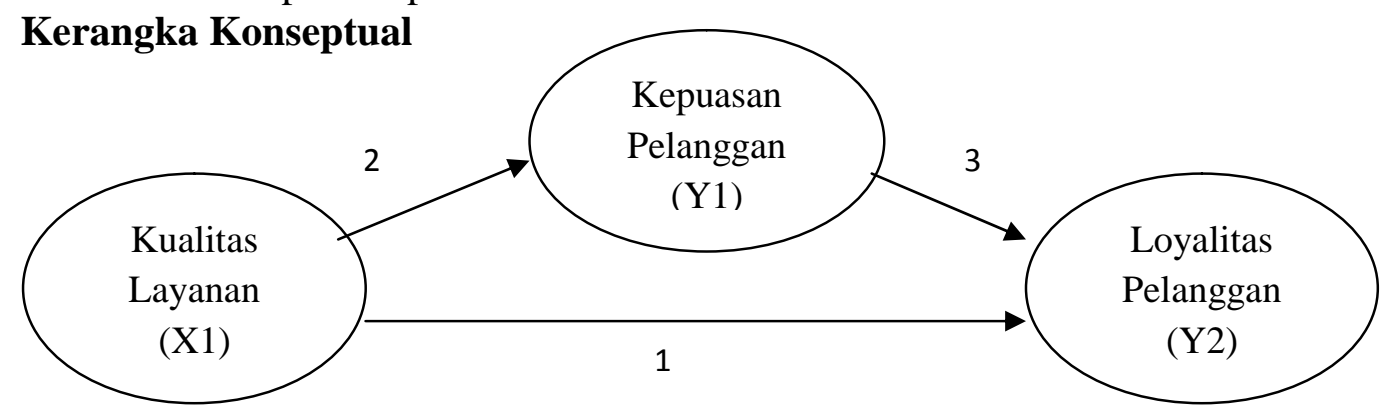

Gambar 1: konseptual penelitian

Kheng et al (2010), Dewi Desrika (2013), Agung (2006), Ishak dan Luthfi (2011) 


\section{Hipotesis \\ $\mathrm{H}_{1}=$ Kualitas Pelayanan berpengaruh signifikan terhadap kepuasan pelanggan pada Bank Muamalat di Kota Jombang. \\ $\mathrm{H}_{2 \mathrm{a}}=$ Kepuasan berpengaruh signifikan terhadap loyalitas pelanggan pada Bank Muamalat di Kota Jombang \\ $\mathrm{H}_{2 \mathrm{~b}}=$ Kualitas pelayanan berpengaruh signifikan terhadap loyalitas pelanggan pada Bank Muamalat di Kota Jombang \\ $\mathrm{H}_{2 \mathrm{c}}=$ Kualitas Pelayanan berpengaruh signifikan terhadap loyalitas pelanggan yang dimediasi oleh kepuasan di Bank Muamalat Jombang}

\section{METODE PENELITIAN \\ Rancangan Penelitian}

Penelitian ini merupakan penelitian kuantitatif yang dirancang untuk menentukan pengaruh antara variabel independen yaitu kualitas pelayanan sebagai variabel bebas terhadap variabel dependen yaitu loyalitas pelanggan terikat dan kepuasan pelanggan sebagai variabel intervening. Metode yang dipakai dalam penelitian ini adalah metode survey, yaitu responden diberi beberapa pernyataan dalam bentuk angket. Populasi dalam penelitian ini adalah para nasabah Bank Muamalat dengan menggunakan sampel sebanyak 90 nasabah. Untuk menganalisis data peneliti menggunakan regresi untuk melihat pengaruh langsung dengan menggunakan bantuan program SPSS windows Release 14.0 dan menggunakan Analysis Sobel test untuk melihat pengaruh secara tidak langsung.

\section{Definisi operasional dan pengukuran variabel}

Ada tiga definisi operasional variabel dalam penelitian ini yaitu definisi operasional variabel kualitas pelayanan $(\mathrm{X})$ sebagai variabel independent, Kepuasan Pelanggan $\left(\mathrm{Y}_{1}\right)$ sebagai variabel intervening atau mediasi, dan Loyalitas Pelanggan $\left(\mathrm{Y}_{2}\right)$ sebagai variabel dependen.

1. Kualitas pelayanan (X). Kualitas pelayanan menurut Tjiptono, Chandra dan Adriana (2007), diartikan sebagai produk yang bebas cacat, dengan kata lain produk sesuai dengan standar (target sasaran atau persyaratan yang bisa didefinisikan, diobservasi dan diukur). Kualitas pelayanan adalah nilai pelayan yang diberikan oleh karyawan Bank Muamalat kepada nasabah yang menggunakan jasa yang disediakan. Mengukur kualitas pelayanan digunakan lima indikator dari Tjiptono, Chandra dan Adriana (2007) yaitu : 1) Tangible, 2) Reliability, 3) Responsiveness, 4) Assurance, 5) Emphaty

2. Kepuasan Pelanggan ( $\left.\mathrm{Y}_{1}\right)$. Menurut Mowen dan Minor (2007), Kepuasan konsumen (Consumer Satisfaction) didefinisikan sebagai keseluruhan sikap yang ditunjukkan konsumen atas barang atau jasa setelah konsumen memperoleh dan menggunakannya. Kepuasan pelanggan sangat bergantung pada persepsi dan harapan pelanggan. Kepuasan nasabah adalah perasaan dan penilaian nasabah di Bank Muamalat terhadap pelayanan yang diberikan. Mengukur kepuasan nasabah digunakan indikator yang diadopsi dari penelitian sudarsono (2008) yaitu Perasaan puas atas perhatian dan pelayanan yang diberikan

3. Loyalitas Pelanggan $\left(\mathrm{Y}_{2}\right)$. Menurut Lupiyoadi (2009) loyalitas secara harfiah diartikan sebagai kesetiaan, yaitu kesetiaan seseorang terhadap suatu objek. Loyalitas sebagai kondisi dimana pelanggan mempunyai sikap positif terhadap suatu merek, mempunyai komitmen terhadap merek tersebut, dan bermaksud meneruskan pembeliannya dimasa mendatang. Ini berarti loyalitas selalu berkaitan dengan 
preferensi pelanggan dan pembelian aktual. Loyalitas pelanggan adalah perilaku positif konsumen untuk dapat melakukan pembelian kembali di Bank Muamalat. Mengukur niat perilaku membeli kembali digunakan indikator dari Tjiptono (2002) yaitu: 1) Penggunaan jasa kembali, 2) Merekomendasikan merek tersebut pada orang lain.

\section{Pengukuran Variabel}

Skala pengukuran yang digunakan dalam penelitian ini adalah skala likert. Menurut Sugiyono skala Likert digunakan untuk mengukur sikap, pendapat, dan persepsi seseorang atau sekelompok orang tentang fenomena sosial. Dengan skala Likert, maka variabel yang akan diukur dijabarkan indikator variabel. Kemudian indikator tersebut dijadikan sebagai titik tolak untuk menyusun item-item instrumen yang dapat berupa pertanyaan atau pernyataan.

Tabel 1: Kisi-kisi Instrumen Penelitian

\begin{tabular}{|c|c|c|c|}
\hline Variabel & Dimensi & Item/ Butir & Sumber \\
\hline $\begin{array}{l}\text { Kualias } \\
\text { pelayanan } \\
\text { (X) }\end{array}$ & $\begin{array}{l}\text { 1. Tangible } \\
\text { 2. Reliability } \\
\text { 3. Responsiveness } \\
\text { 4. Assurance }\end{array}$ & $\begin{array}{l}\text { 1. Ruang tunggu pelayanan yang nyaman } \\
\text { 2. Rancangan gedung yang menarik } \\
\text { 3. Memiliki slip transaksi yang lengkap } \\
\text { 4. Kerapian busana yang dikenakan karyawan } \\
\text { 5. Proses kredit tidak berbelit-belit } \\
\text { 6. Memberi layanan tepat waktu } \\
\text { 7. Daya tangkap seluruh karyawan membantuPelanggan } \\
\text { 8. Meminta maaf jika nasabah menunggu lama } \\
\text { 9. Kecepatan karyawan menangani masalah nasabah } \\
\text { 10. Ketanggapan menjawab pertanyaan individu } \\
\text { 11. Memberikan layanan transaksi yang cepat kepada } \\
\text { nasabah } \\
\text { 12. Membantu menuliskan jika nasabah mengalami } \\
\text { kesulitan bertransaksi } \\
\text { 13. Keamanan kartu kredit dari penyalahgunaan } \\
\text { 14. Memberi penjelasan tentang semua jens tabungan } \\
\text { kepada nasabah baru } \\
\text { 15. Kerahasiaan Nasabah terjaga } \\
\text { 16. Nasabah mendapat layanan transaksi dari seorang } \\
\text { karyawan yang berpengalaman tentang tabungan } \\
\text { Muamalat } \\
\text { 17. Kemauan berkomunikasi dengan pelanggan } \\
\text { 18. Memberi ucapan salam pada saat bertransaksi } \\
\text { 19. Memberi perhatian yang baik kepada nasabah } \\
\text { 20. Sungguh-sungguh memperhatikan kepentingan } \\
\text { nasabah }\end{array}$ & $\begin{array}{l}\text { Tjiptono, } \\
\text { Chandra, } \\
\text { Adriana } \\
(2007),\end{array}$ \\
\hline $\begin{array}{l}\text { Kepuasan } \\
\text { pelanggan } \\
\quad(\mathrm{Y} 1)\end{array}$ & $\begin{array}{l}\text { Perasaan puas } \\
\text { atas perhatian } \\
\text { dan pelayanan } \\
\text { yang diberikan }\end{array}$ & $\begin{array}{l}\text { 21. Customer Service membantu nasabah ketika } \\
\text { mempunyai masalah. } \\
\text { 22. Layanan transaksi sesuai dengan harapan nasabah } \\
\text { 23. Tidak ada komplain atau keluhan terhadap } \\
\text { pelayanan } \\
\text { 24. Nasabah mendapatkan layanan transaksi yang terbaik }\end{array}$ & $\begin{array}{l}\text { Sudarsono } \\
(2008)\end{array}$ \\
\hline $\begin{array}{l}\text { Loyalitas } \\
\text { Pelanggan } \\
\text { (Y2) }\end{array}$ & $\begin{array}{l}\text { 1. Penggunaan jasa } \\
\text { kembali }\end{array}$ & $\begin{array}{l}\text { 25. Ketersediaan menggunakan produk lain yang } \\
\text { ditawarkan bank muamalat } \\
\text { 26. Nasabah ingin terus melakukan transaksi di Bank } \\
\text { Muamalat dalam jangka panjang } \\
\text { 27. Ketersediaan menginformasikan kepada orang lain } \\
\text { apabila ada produk baru dari bank muamalat } \\
\text { 28. Nasabah ingin menyarankan orang lain untuk } \\
\text { bertransaksi di Bank Muamalat }\end{array}$ & $\begin{array}{l}\text { Tjiptono } \\
(2002)\end{array}$ \\
\hline
\end{tabular}


Dari penjabaran indikator tersebut dapat dirinci kembali secara operasional menjadi item-item beserta jawabannya yang terdapat dalam angket penelitian. Peneliti menggunakan 5 (lima) alternatif pilihan jawaban yang disediakan dalam angket yang telah dimodifikasi dari skala Likert.

\section{Populasi dan sampel}

Populasi pada penelitian ini adalah seluruh nasabah pada Bank Muamalat di Jombang tepatnya di Jl. Presiden KH. Abdurrahman Wahid no.22 Jombang. Penetapan jumlah populasi dalam penelitian ini di ambil dari jumlah pelanggan rata-rata sebanyak 65 orang perhari atau 912 pelanggan selama dua minggu masa penelitian.

Menurut Arikunto (2006) sampel adalah sebagian atau wakil dari populasi yang akan diteliti. Pengambilan sampel diperoleh berdasarkan rumus slovin. Rumus slovin digunakan unuk menenukan beberapa minimal sampel yang dibutuhkan jika ukuran populasi diketahui. Dari hasil perhitungan diketahui jumlah sampel sebanyak $=90,11$ dibulatkan menjadi 90 orang.

Dalam penelitian ini metode pengambilan sampel menggunakan Non probability Sampling, dengan teknik sampel aksidental yaitu teknik penentuan sampel berdasarkan kebetulan, yaitu siapa saja yang secara kebetulan bertemu dengan peneliti dapat digunakan sebagai sampel, bila dipandang orang yang ditemui itu cocok sebagai sumber data. Sugiyono (2004)

\section{Jenis dan sumber data}

1. Data primer adalah data yang diperoleh secara langsung dari sumbernya. Jenis data primer yang digunakan oleh peneliti adalah dengan cara menggunakan angket yang diperoleh dari responden secara langsung.

2. Data sekunder adalah sumber data yang diperoleh secara tidak langsung, seperti mendapatkan informasi dari pihak lain atau melalui dokumen. Data sekunder dugunakan untuk mengambil dokumen dari bank terkait dengan jumlah nasabah, struktur organisasi dan dokumen-dokumen yang mendukung penelitian. Jenis data sekunder yang diperoleh oleh peneliti adalah dari Bank Muamalat.

\section{Analisis Jalur (Path Analysis)}

Pengujian hipotesis penelitian dilakukan dengan menggunakan model analisis jalur (path analysis) dan pengolahan data menggunakan program SPSS. Analisis jalur merupakan model dasar yang digunakan untuk menganalisis jalur dalam mengestimasi kekuatan dari hubungan-hubungan kausal yang digambarkan dalam path model. Analisis jalur digunakan karena diduga terdapat hubungan antar variabel bebas, sehingga terdapat pengaruh langsung dan tidak langsung terhadap variabel terikat. Tahap analisis jalur dalam penelitian ini terdapat dua sub struktural :

1. $\mathrm{Y}_{1}=\mathrm{Y}_{1} \mathrm{X}+\mathrm{e}_{1}$

2. $\mathrm{Y}_{2}=\mathrm{Y}_{2} \mathrm{X}+\mathrm{Y}_{1+} \mathrm{e}_{1}$

Dimana $\mathrm{X}$ adalah kualitas pelayanan, $\mathrm{Y}_{1}$ kepuasan dan $\mathrm{Y}_{2}$ loyalitas pelanggan.

\section{Analisis Mediasi Menggunakan Sobel Test}

Untuk mengetahui pengaruh variabel mediasi dalam penelitian ini yaitu dengan menggunakan bantuan software sobel test. Uji sobel ini dilakukan dengan cara menguji kekuatan pengaruh tidak langsung antara variabel Independent (X) kepada Variabel dependent (Y2) melalui variabel mediasi, yaitu kepuasan pelanggan (Y1). 


\section{HASIL PENELITIAN DAN PEMBAHASAN Deskripsi Hasil Jawaban Kualitas Pelayanan (X)}

Pengukuran Variabel Kualitas Pelayanan dari 20 item pernyataan dengan skala pengukuran satu sampai lima, pernyataan tersebut diantaranya adalah Ruang tunggu pelayanan yang nyaman, Rancangan gedung yang menarik, Memiliki slip transaksi yang lengkap, Kerapian busana yang dikenakan karyawan,Proses kredit tidak berbelit-belit, Memberi layanan tepat waktu, Daya tangkap seluruh karyawan membantu pelanggan, Meminta maaf jika nasabah menunggu lama, Kecepatan karyawan menangani masalah nasabah, Ketanggapan menjawab pertanyaan individu, Memberikan layanan transaksi yang cepat kepada nasabah, Membantu menuliskan jika nasabah mengalami kesulitan bertransaksi, Keamanan kartu kredit dari penyalahgunaan, Kerahasiaan Nasabah terjaga, Memberi penjelasan tentang semua jenis tabunngan kepada nasabah baru, Nasabah mendapat layanan transaksi dari seorang karyawan yang berpengalaman tentang tabungan Muamalat, Kemauan berkomunikasi dengan pelanggan, Memberi ucapan salam pada saat bertransaksi, Memberi perhatian yang baik kepada nasabah, Sungguhsungguh memperhatikan kepentingan nasabah.

Dari hasil penelitian menunjukkan bahwa sebagian besar responden menjawab ke arah positif (setuju) terhadap pernyataan yang diajukan yaitu dengan rata-rata prosentase 56,6\%. Dari hasil rerata indikator kualitas pelayanan diperoleh mean sebesar 3,93\%. Hal tersebut, menggambarkan bahwa kualitas pelayanan di Bank Muamalat adalah mendekati ke arah yang bagus.

\section{Deskripsi Hasil Jawaban Kepuasan Pelanggan (Y1)}

Pengukuran Variabel kepuasan Pelanggan terdiri dari 4 (empat) item pernyataan dengan skala pengukuran satu sampai lima. Pernyataan tersebut diantaranya adalah Customer Service membantu nasabah ketika mempunyai masalah, Layanan transaksisesuai dengan harapan nasabah, Tidak ada komplain atau keluhan terhadap pelayanan, Nasabah mendapatkan layanan transaksi yang baik. Dari hasil perhitungan menunjukkan bahwa sebagian besar responden menjawab ke arah positif (setuju) yaitu dengan rata-rata hasil prosentase $59,45 \%$. Dari hasil rerata indikator kepuasan pelanggan diperoleh nilai mean dengan prosentase sebesar 4,01\%. Hal tersebut, menunjukkan bahwa kepuasan pelanggan di Bank Muamalat dikatakan puas/ baik.

\section{Deskripsi Hasil Jawaban Loyalitas Pelanggan (Y2).}

Pengukuran Variabel Loyalitas Pelanggan terdiri dari 4 (empat) item pernyataan dengan skala pengukuran satu sampai lima. Pernyataan tersebut diantaranya adalah Ketersediaan menggunakan produk lain yang ditawarkan bank muamalat, Nasabah ingin terus melakukan transaksi di Bank Muamalat dalam jangka panjang, Ketersediaan menginformasikan kepada orang lain apabila ada produk baru dari bank muamalat, Nasabah meyakini produk yang ditawarkan bank muamalat adalah yang terbaik dibandingkan produk bank lainnya. Dari hasil perhitungan menunjukkan bahwa sebagian besar responden menjawab ke arah positif (setuju) yaitu dengan rata-rata hasil prosentase 58,8\%. Dari hasil rerata indikator Loyalitas Pelanggan diperoleh nilai mean dengan hasil prosentase sebesar 3,74\% Hal tersebut, menunjukkan bahwa Loyalitas Pelanggan di Bank Muamalatmendekati baik.

\section{Pengujian Hipotesis}

\section{H1 = Kualitas Pelayanan berpengaruh terhadap Kepuasan Pelanggan.}

Hasil pengujian secara langsung antara Kualitas Pelayanan terhadap kepuasan pelanggan dapat dibuktikan dengan perhitungan secara langsung melalui regresi. 
Berdasarkan output komputer mengenai koefisien korelasi, diperoleh koefisien korelasi sebesar 0.652 dan koefisien ini bertanda positif.

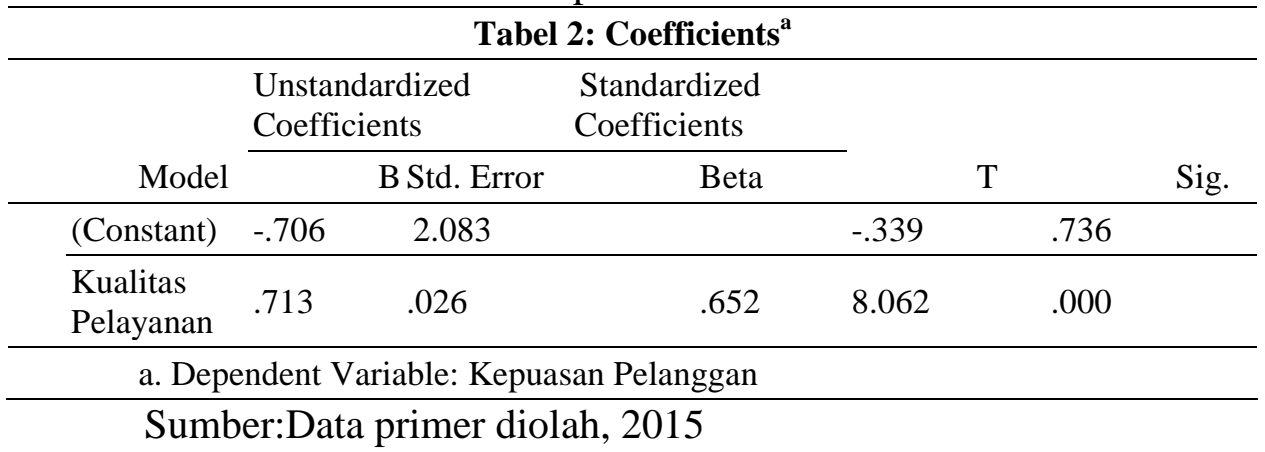

Berdasarkan hasil analisis regresi dengan menggunakan output komputer diatas maka dapat dilihat persamaan regresinya adalah $\mathrm{Y} 1=0,706+0,713 \mathrm{X} 1+$. Persamaan garis regresi yang positif ini dapat disimpulkan bahwa apabila kualitas pelayanan yang baik, maka pelanggan juga akan merasa puas. Artinya apabila semakin baik kualitas pelayanan maka kepuasan pelanggan juga dapat dikatakan memuaskan.

Adapun besarnya pengaruh kualitas pelayanan terhadap kepuasan pelanggan dapat dilihat pada output komputer berikut :

\begin{tabular}{|c|c|c|c|c|}
\hline \multirow{3}{*}{ Model } & \multicolumn{4}{|c|}{ Tabel 3: Model Summary } \\
\hline & $\mathrm{R}$ & R Square & $\begin{array}{l}\text { Adjusted } \\
\text { R Square }\end{array}$ & $\begin{array}{l}\text { Std. Error } \\
\text { of the Estimate }\end{array}$ \\
\hline & $1.652^{\mathrm{a}}$ & .425 & .418 & 1.45032 \\
\hline
\end{tabular}

Sumber:Data primer diolah, 2015

Berdasarkan output komputer diatas dapat dijelaskan bahwa diperoleh nilai $\mathrm{R}$ square sebesar 0.425 . Hal ini berarti bahwa variabel kualitas pelayanan terhadap kepuasan pelanggan sebesar 42,5\%, dan sisanya sebesar 57,5\% dipengaruhi faktor lain.

\section{H1 = Kualitas pelayanan berpengaruh terhadap Kepuasan Pelanggan}

Hasil pengujian $\mathrm{H} 1$ terbukti bahwa kualitas pelayanan berpengaruh signifikan terhadap kepuasan, artinya semakin baik kualitas pelayanan maka kepuasan pelanggan juga dapat semakin baik, yang berarti hipotesis pertama yang diajukan dalam penelitian ini dapat diterima. Dalam penelitian ini juga mendukung dari hasil penelitian sebelumnya mengenai kualitas pelayanan terhadap kepuasan pelanggan yang dilakukan oleh Hui dkk (2009) menyatakan bahwa, Kualitas pelayanan berpengaruh positif terhadap kepuasan pelanggan. Sehingga dalam penelitian ini mampu menguatkan teori yang dikemukakan oleh Kotler dan Keller (2007) Menyatakan bahwa kualitas pelayanan berpengaruh dan kepuasan konsumen akan membentuk minat membeli atau menggunakan kembali suatu produk.
$\mathrm{H}_{2 \mathrm{a}}$ Dan $\mathrm{H}_{2 \mathrm{~b}}=$ Pengaruh Kualitas Pelayanan dan Kepuasan Pelanggan Terhadap Loyalitas Pelanggan melalui
Pengujian $\mathrm{H}_{2 \mathrm{a}}$ dan $\mathrm{H}_{2 \mathrm{~b}}$ dapat dibuktikan dengan perhitungan secara langsung analisis regresi. 


\begin{tabular}{|c|c|c|c|c|c|}
\hline \multicolumn{6}{|c|}{ Tabel 4: Coefficients ${ }^{a}$} \\
\hline & $\begin{array}{l}\text { Unsta } \\
\text { Coeffi }\end{array}$ & $\begin{array}{l}\text { dardized } \\
\text { ients }\end{array}$ & $\begin{array}{l}\text { Standardized } \\
\text { Coefficients }\end{array}$ & & \\
\hline Model & & Std. Error & Beta & $\mathrm{t}$ & Sig. \\
\hline (Constant) & 1.677 & 1.614 & & 1.039 & .302 \\
\hline Kualitas Pelayanan (x) & 058 & .027 & .162 & 2.151 & .034 \\
\hline Kepuasan Pelanggan (y1) & 806 & .083 & .733 & 9.766 & .000 \\
\hline
\end{tabular}

a. Dependent Variable: Loyalitas Pelanggan

Sumber:Data primer diolah, 2015

Berdasarkan hasil analisis regresi diatas dengan menggunakan output komputer maka dapat dijelaskan bahwa kualitas pelayanan dan kepuasan pelanggan berpengaruh terhadap loyalitas pelanggan adalah signifikan. Dengan persamaan regresi Y2 $=-1,677$ $+0,058 \mathrm{X} 1+0,806 \mathrm{Y} 1+$. Persamaan garis regresi yang positif ini dapat dilihat bahwa semakin baik kualitas pelayanan dan juga diperoleh kepuasan pelanggan oleh konsumen maka, loyalitas pelanggan juga akan meningkat pula.

Adapun besarnya pengaruh antara kualitas pelayanan dan kepuasan pelanggan terhadap loyalitas pelanggan di uji dengan ketepatan model yang dapat dilihat pada output komputer berikut :

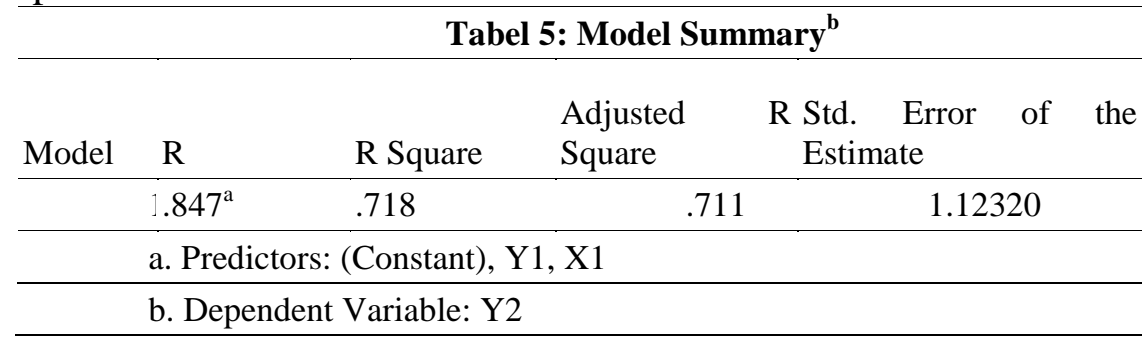

Sumber:Data primer diolah, 2015

Berdasarkan output komputer diatas dapat dijelaskan bahwa diperoleh nilai $\mathrm{R}$ square sebesar 0.718. Hal ini berarti bahwa variabel kualitas pelayanan dan kepuasan pelanggan memberi sumbangan pengaruh yang sangat besar terhadap loyalitas pelanggan sebesar $71,8 \%$, dan sisanya sebesar $28,2 \%$ disebabkan faktor lain yang tidak diteliti dalam penelitian ini.

Selanjutnya untuk melihat pengaruh langsung dan tidak langsung dapat dilihat dalam pola analisis jalur, dalam penelitian ini ditunjukkan pada:

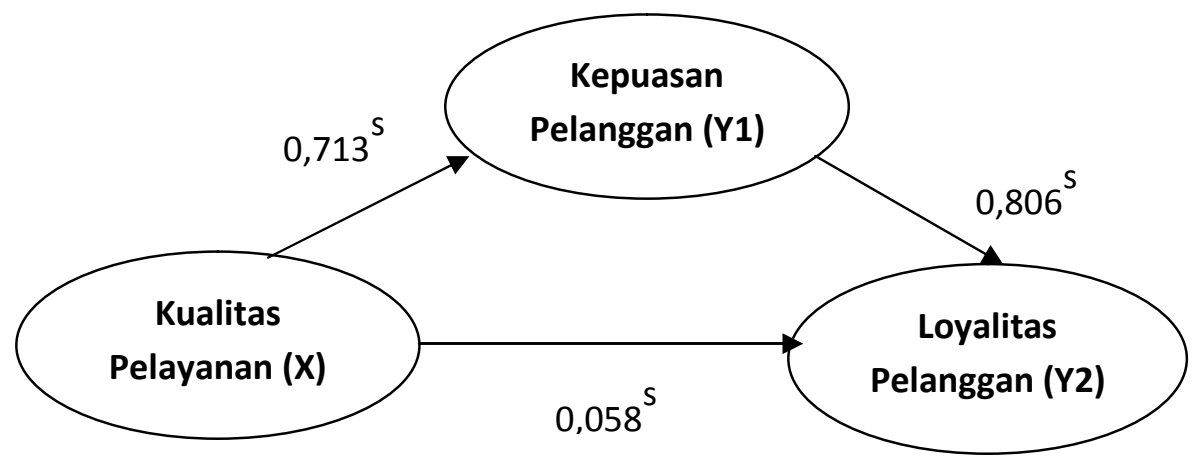

Gambar 2: analisis jalur

S: Signifikan 
Hasil analisis jalur menunjukkan bahwa kualitas pelayanan berpengaruh langsung dan juga berpengaruh tidak langsung pada loyalitas pelanggan melalui kepuasan pelanggan sebagai variabel mediasi. Besarnya pengaruh langsung adalah 0,162 sedangkan besarnya pengaruh tidak langsung harus dihitung dengan mengalikan koefisien tidak langsungnya yaitu $(0,652) \times(0,733)=0,477$ Maka kualitas pelayanan berpengaruh positif terhadap loyalitas pelanggan melalui kepuasan pelanggan yaitu sebesar 0,477 .

Selanjutnya untuk menguji apakah pengaruh ini signifikan ataukah tidak, maka diperlukan adanya uji sobel test sebagai berikut.

\section{$\mathbf{H}_{2 \mathbf{a}}=$ Variabel Kepuasan Terhadap Loyalitas Pelanggan}

Hasil pengujian $\mathrm{H}_{2 \mathrm{a}}$ terbukti bahwa kepuasan berpengaruh signifikan terhadap loyalitas pelanggan, dari hasil penelitian terlihat ada pengaruh antara kepuasan dengan loyalitas pelanggan. Hal ini sesuai dengan penelitian sebelumnya yang dilakukan oleh Asmai Ishak (2011) yakni ada pengaruh yang signifikan antara kepuasan terhadap loylitas. Penelitian ini juga mendukung teori yang dikemukakan oleh Kotler (2007), yang menyatakan bahwa Kepuasan pelanggan adalah Perasaan senang atau kecewa seseorang yang muncul setelah membandingkan antara persepsi atau kesan pelanggan terhadap hasil suatu produk dan harapan-harapan pelanggan. Keberhasilan perusahaan apabila karyawan mampu memberikan pelayanan yang baik, sehingga pelanggan merasa puas dan di mata pelanggan citra perusahaan menjadi baik dan bersifat positif. Hal tersebut dapat menumbuhkan loyalitas pelanggan Kotler (2007).

\section{$\mathbf{H}_{2 \mathrm{~b}=}$ Kualitas Pelayanan Terhadap Loyalitas Pelanggan}

Hasil pengujian $\mathrm{H}_{2 \mathrm{~b}}$ terbukti bahwa Kualitas pelayanan berpengaruh signifikan terhadap loyalitas pelanggan, artinya apabila semakin baik kualitas pelayanan maka akan tercipta loyalitas pelanggan.Penelitian ini juga mendukung hasil penelitian sebelumnya mengenai kualitas pelayanan yang dilakukan oleh Puspitasari dan Edris (2011) terbukti "kualitas layanan berpengaruh secara langsung terhadap loyalitas" diterima kebenarannya.

\section{$\mathbf{H}_{2 \mathrm{c}}$ : Kualitas Pelayanan Terhadap Loyalitas Pelanggan yang di Mediasi Kepuasan Pelanggan}

Untuk mengetahui pengaruh variabel mediasi dalam penelitian ini yaitu dengan menggunakan bantuan software sobel test. Uji sobel ini dilakukan dengan cara menguji kekuatan pengaruh tidak langsung antara variabel Independent (X) kepada Variabel dependent (Y2) melalui variabel mediasi, yaitu kepuasan pelanggan (Y1).

Adapun hasil dari uji sobel test dapat dilihat pada hasil output dibawah ini : 


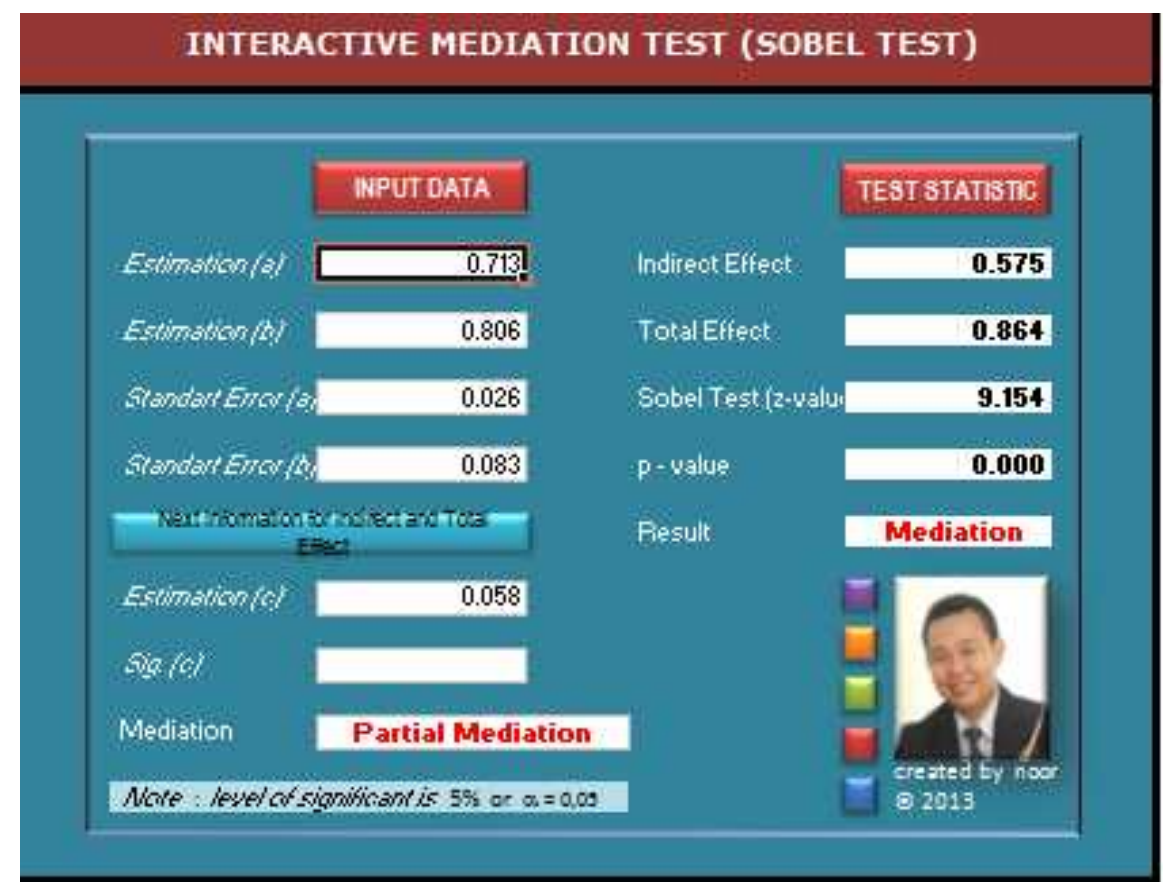

\section{Gambar 3: Uji Sobel Test Kepuasan Pelanggan sebagai Variabel Mediasi antara Kualitas Pelayanan terhadap Loyalitas.}

Berdasarkan input data pada sobel test di atas dapat dijelaskan bahwa nilai Estimation (a) sebesar 0.713, Estimation (b) sebesar 0.806, Estimation (c) sebesar 0.058, standart Error (a) sebesar 0.026 dan standart Error (b) sebesar 0.083.

Adapun output dari test statistic diperoleh hasil Indirect Effect sebesar 0.575 Total Effect sebesar 0.864, Sobel Test (z-value) 9.154 dan p-value 0.000 dan hasil output diatas menyatakan bahwa kepuasan pelanggan dalam penelitian ini adalah sebagai variabel Mediasi antara kualitas pelayanan terhadap loyalitas pelanggan dengan type partial mediation. Artinya, ada pengaruh secara langsung dan tidak langsung antara kualitas pelayanan terhadap loyalitas pelanggan yang dimediasi oleh kepuasan pelanggan.

Hasil pengujian Type of Mediation dalam uji sobel test adalah partial mediation, artinya bahwa ada pengaruh secara langsung dan tidak langsung variabel kualitas pelayanan terhadap loyalitas pelanggan. Penelitian ini juga mendukung hasil penelitian sebelumnya yang dilakukan oleh Alfian, Raharjo (2010), yang menyatakan bahwa ada pengaruh secara langsung dan tidak langsung antara kualitas produk terhadap loyalitas konsumen yang dimediasi oleh kepuasan.

\section{E. PENUTUP}

Berdasarkan 'hasil penelitian dapat diambil beberapa kesimpulan yaitu: 1) Kepuasan pelanggan dapat dibangun dari Kualitas pelayanan yang baik, 2) Kepuasan yang dirasakan pelanggan dapat membangun sebuah loyalitas pelanggan, 3) Untuk membangun loyalitas pelanggan, dapat melalui kepuasan yang dirasakan oleh pelanggan dan juga dari kualitas pelayanan yang baik dari Bank Muamalat Jombang.

Dari simpulan diatas disarankan kepada Bank Muamalat Jombang untuk memperhatikan faktor Kualitas Pelayanan pada dimensi: 1) keandalan (reliability), yaitu dalam hal ketepatan waktu, hendaknya pihak Bank Muamalat lebih meningkatkan 
kedisiplinan para pegawainya terutama yang berhubungan dengan pelanggan langsung, 2) Dimensi jaminan (assursnce), terkait dengan penjelasan mengenai semua jenis tabungan kepada nasabah baru, hendaknya pihak bank khususnya bagian customer service menjelaskan lebih detail mengenai semua jenis tabungan kepada pelanggan sehingga para pelanggan mendapatkan jaminan tentang keuntungan serta resiko menabung di Bank Muamalat.

\section{DAFTAR PUSTAKA}

Atmojo, Agong Purwo. 2010. Analisa Pengaruh Kualitas Layanan, Nilai Nasabah dan Atribut Produk Islam Terhadap Kepuasan Nasabah

Desrika, Dewi. 2003. Pengaruh Kualitas Pelayanan Terhadap Tingkat Kepuasan Nasabah Pada PT. Pegadaian (Persero) Cabang Tapi Bandar Padang

Edris, Muchamad dan Puspitasari, Mei gawati. 2011. PengaruhKualitas Layanan Terhadap Loyalitas Dengan Mediasi Kepuasan Pasien Rawat Inap Pada Keluarga Sehat Hospital Pati

Griffin, Jill. 2003. Customer Loyalty : Menumbuhkan dan Mempertahankan Pelanggan. Jakarta : Airlangga

Heri, Sudarsono (2008), Bank \& Lembaga Keuangan Syariah, Yogyakarta: Ekonisia, Cetakan ke dua

Ishak, Asmai. Zafri Luthfi. 2011. Pengaruh Kepuasan dan Kepercayaan Konsumen Terhadap Loyalitas

Kheng, Lo Liang. 2010. The Impact of Service Quality on Customer Loyalty. A Study of Bank in Penang, Malaysia

Kotler, Philip dan Keller, Kevin Lane. 2007. Manajemen Pemasaran Edisi 12. Jakarta : PT. Indeks

Kotler. Philip dan Kevin Lane Keller. 2009. Manajemenn Pemasaran, Jakarta : Penerbit Erlangga, edisi 13. Jilid 2

Kotler, Philip, 1997. Manajemen Pemasaran. Jakarta: Prenhallindo.

Kotler, Philip, 2000. Manajemen Pemasaran, PT. Prenhallindo, Jakarta.

Kotler, Philip. 2007. Majaemen Pemasaran, Analisa Perencanaan, Pengendalian Prentice Hall, Edisi Bahasa Indonesia, Jakarta: Salemba Empat

Lupipyoadi, Rambat 2009. Manajemen Pemasaran Jasa. Jakarta: Salemba Empat

Mowen John.C dan Michael Minor. 2007. Perilaku Konsumen Jilid 2 Edisi ke-5: Erlangga

Prasetyo, Widiyanto Bangun. 2007. Pengaruh Kualitas Pelayanan, Kepercayaan dan Keupasan Terhadap Loyalitas (studi pada swalayan luwes purwodadi)

Raharjo, Alfian. 2010. Pengaruh Kepuasan Terhadap Loyalitas Pelanggan Pengguna Kartu "AS"

Sugiyono. (2004). Metode Penelitian Bisnis. Alfabeta, CV. Bandung

Tjiptono Fandy, Gregorius Chandra, dan Dadi Adriana. 2007. Pemasaran Strategik, Andi. Yogyakarta

Tjiptono, Fandy. (2002). Strategi Pemasaran. Andi, Yogyakarta

Tjiptono, Fandy. 2006, Manajemen Pelayanan Jasa, Penerbit Andi, Yogyakarta

Yu Sum, Cheng and Leung Hui, Chi. 2009. "Salespersons' Service Quality and Customer Loyalty in Fashion Chainstores A study in Hong Kong Retail Stores". Journal of Fashion Marketing and Management Vol. 13 No. 1, 2009 pp. 98-108. DOI 10.1108/13612020910939905. 